\title{
Departing toward Survival: Reconsidering the Language of Trauma in Cathy Caruth, Ingeborg Bachmann and W. G. Sebald
}

\author{
Kathleen Ong XinWei \\ Columbia University Narrative Medicine Program, Columbia University in the City of New York, New York, USA \\ Email: kathleenongxinwei@gmail.com
}

Received 7 July 2014; revised 3 August 2014; accepted 8 October 2014

Copyright (C) 2014 by author and Scientific Research Publishing Inc. This work is licensed under the Creative Commons Attribution International License (CC BY). http://creativecommons.org/licenses/by/4.0/

(c) (i) Open Access

\begin{abstract}
Little has been said in trauma studies about the ability or inability of traumatized characters depicted by traumatized writers to recover accounts of self from the aseptic reiterations of a language unable to articulate the unspeakable event of trauma. This paper argues that Cathy Caruth's recent emphasis upon a "language of ashes"-derived from a "language of the life drive" departing from a "language of the death drive"-provides a framework for examining the extent to which traumatized textualities are able to apprehend their seeming enervating repetitions of the death drive as textual constructs able to be written on and read. I posit that the literary characters in the fictions of Ingeborg Bachmann and W. G. Sebald occupy opposing ends of the ambit of the life and death drives, and aver that the contrasting ways they perform the repetitiveness of personal and/or national trauma come close to enacting, respectively, the languages of the "death drive" and the "life drive". I demonstrate the extent to which they are able to extricate the language used from their singular historical experiences of trauma. In this way, I argue that Caruth's attempt to identify the site within history where trauma can be creatively animated sets a productive framework for examining how trauma can either metabolize an individual into foreclosing the world, or create a continuing dialogue with loss for the unfolding of a world-in-becoming.
\end{abstract}

Keywords

Trauma, Literature, Post WW2, European Literature, Language

\section{Introduction}

Recent representations of traumatic memories in cultural analysis, identity politics, medical discourse and literary studies have displayed a proclivity toward texts able to transmit the experience of trauma directly to read- 
ers $^{1}$. However, less has been said about the ability or inability of traumatized characters, depicted by traumatized writers, to recover accounts of self from the aseptic reiterations of a language unable to articulate the unspeakable event of trauma. This paper argues that Cathy Caruth's recent emphasis of a "language of the life drive" departing from a "language of the death drive" provides a framework for examining the extent to which traumatized textualities are able to apprehend and seize themselves and their seeming enervating repetitions of the death drive as textual constructs able to be written on and be read. I aver that the fictional protagonists in the prose of Ingeborg Bachmann and Winfried Georg Sebald utilize respectively the "language of the death drive" and the "language of the life drive", and demonstrate the extents that they are able to extricate the language used from their singular historical experiences of trauma. I show how the ability to do so enables them to-as Caruth posits-depart from the dull repetitions of the death drive by identifying creativity within the compulsive reiterations themselves. I also advance that Caruth's "language of the life drive" and "language of the death drive" provide fecund ground for reconsidering the future of scholarship in both Bachmann and Sebald's oeuvres. This is especially so for the former, which has gained attention for the impasse reached, mostly due to Bachmann's family stalling the publication process of the remainder of her work ${ }^{2}$. By tracing the ways in which the female protagonists in her prose fail to reckon with the compulsively recursive language that they employ in the wake of trauma, this paper aspires to contribute to the forward trajectory in Bachmann scholarship by articulating and subsequently gaining a certain amount of mastery over its seeming stagnation.

\subsection{Traumatized Textualities Performing Trauma}

"Trauma” has come to designate the expressive limit caused by an event so life-threatening it displaces preconceived notions of the world in intolerable ways. Trauma studies, in their aim to illuminate a range of scarring experiences of aggression such as rape, abuse and incarceration, have demonstrated a tendency to turn toward literary texts that represent trauma as a way to reckon with, work through, and understand traumatic history and the altered architecture of memory the traumatized experience. Of course, this observed proclivity could be viewed as incongruous, as it implies literature's ability to express what has already been acknowledged is inexpressible. However, above and over other disciplines, literary studies is the only one that embraces and configures the nebulous space not just between knowing and not knowing, but between speaking and the inability to speak as well. Literature is thus able to give voice to trauma because it licenses resistance toward conventional narrative structures and linear temporalities through its ability to make wounds perceivable and silences audible. In Unclaimed Experience (1996), Caruth states that such representations of traumatic memory engage in a "double telling"; "the oscillation between a crisis of death and the correlative crisis of life: between the story of the unbearable nature of an event and the story of the unbearable nature of its survival" (Caruth, 1996: p. 7, italics in original). In Trauma Fictions (2004), Anne Whitehead advances that this account of self "implicitly repositions the relation between language and the world", resulting in the text shifting from a "reflective" mode "based on a position of self-awareness and self-understanding" to a performative act in which it becomes "imbricated in... attempts to perceive and understand the world" (Whitehead, 2004: p. 11). This performative aspect of textual trauma is what leads Caruth, in Unclaimed Experience, to "trace... the story of the textual itinerary of insistently recurring words or figures" in the texts of Sigmund Freud, Jacques Lacan, Marguerite Duras, and Paul de Man (Caruth, 1996: p. 5). While her recent Literature in the Ashes of History (2013) also addresses traumatic textualities that enact traumatic knowledge as opposed to directly representing it, she attempts a meaningful and unprecedented move in trauma studies by trying to identify the site within history where trauma can be worked through or narrated instead.

\subsection{The Performance of Trauma in Freud's Theory of Trauma}

Taking Freud's Beyond the Pleasure Principle (1920) as the cornerstone of her investigation, Caruth examines the place where history "seems to move forward through the erasure of its own memory" in "the performance of its own disappearance" (Caruth, 2013: p. xi). In his essay, Freud developed the theory of trauma from watching his grandchild Ernst Halberstadt throw small objects away after his mother (Freud's daughter Sophie) had left the room. He advanced that Ernst had reenacted his mother's departure [fort, or gone] in a self-invented game

\footnotetext{
${ }^{1}$ Many trauma scholars have attempted to define the various narrative techniques used to enact trauma; Ronald Granofsky, Dominick LaCapra, Laurie Vickroy, Anne Whitehead and others.

${ }^{2}$ See Göttsche’s (2011) “Research on Ingeborg Bachmann: Quo Vadis?” for an elucidation of the challenges facing Bachmann research.
} 
[Spiel], repeating the painful memory of her departure, loss, and death in order to experience the joy of her return [da, or return]. Consequently, Freud proposed that fort-da was the "complete game-disappearance and return", and that "as a rule one only witnessed its first act, which was repeated untiringly as a game in itself, though there is no doubt that the greater pleasure was attached to the second act” (Freud, 1999: p. 599). From these observations ${ }^{3}$, Freud posited that two main forces - the life drive and the death drive-propel the human psyche. While the life drive concerns itself with self-preservation and emotional/physical gratification, the death drive seeks to re-establish an inanimate state prior to the emergence of life. Accordingly, the struggle for life is subordinate to the death drive, and operates pervasively beneath the whole of psychical life. Freud advanced that "the aim of all life" is therefore "death", and that the origin of the subject and beginnings of life itself are situated in the drive toward death, which has been diverted in order for life to continue.

In Literature in the Ashes of History (2013), Caruth asserts that Freud's essay of repetition-compulsion not only "describes the death drive and its enigmatic move to the drive for life" but also "enacts this drive for life as the very language of the [fort-da] child that encounters, and attempts to grasp, the catastrophes of a traumatic history” (Caruth, 2013: p. 15, italics mine). For Caruth, Beyond the Pleasure Principle, borne from Freud's own traumatic performance of repetition, is his creative way of working through and constructing a new history in the aftermath of his daughter's death. In other words, she asserts that in his attention to the organic desire to return to a primordial, inorganic state, Freud himself acted out his own conjecture of enabling potential "witnessing and history [-making] in creative acts of life" (Caruth, 2013: p. 5). Consequently, the repetition and erasure of representing traumatic memory does not simply represent history, but enacts and creates it through the process of its own erasure instead. This process involves crossing the traumatic memory out while permitting it to remain legible and in place, thus exposing the trace, a transcendental signified already concealed within the language used.

\subsection{The Language of the Life Drive in Representing Trauma}

Taken this way, history can be seen as the constantly revivifying result of creative performances unwillingly (and often unconsciously) produced through the repetition caused by the death drive. For Caruth, Freud's $B e-$ yond the Pleasure Principle consequently advances toward what she calls a "language of the life drive", as opposed to a "language of the death drive" (Caruth, 2013: p. xi). She posits the existence of such a language used in the aftermath of catastrophes, that is able to exceed the pull of the death drive by enacting and therefore mastering its damning repetition; a "language of departure... that does not repeat the unconscious origin of life as death, but creates a history by precisely departing toward survival" (Caruth, 2013: p. 9, italics mine). In general, life after trauma involves attempting to unravel the rigid scaffolds of painful memories that have been displaced outside the psyche, as in psychoanalysis, so as to assimilate them back into lived experience in a manner tolerable to the traumatized. Caruth's use of the term "departing toward survival” therefore suggests the tenacious and willing undertaking to reckon with one's trauma in order to survive; a redemptive feat not just excruciating, but outrageously incongruous with the life drive as well. Since the drive toward this stage of inanimate matter is in direct opposition to life in its complete biological sense, a traumatized person's willing contention with his psychic calamities can thus be seen as a biologically anti-survival undertaking. Caruth asserts that the "language of the death drive" is able to prompt the "language of the life drive", and that it is thus in reckoning with one's trauma within the repetition-compulsion of language used in the aftermath of trauma that an individual may begin to be cured. While this assertion follows Freud's theory of trauma in assuming that the struggle for life is subordinate to the death drive, Caruth's advancement is significant because it accentuates the creative elements at work in constructing history out of the repetitions of trauma (death drive), and the subsequent possibility of creating a new history (life drive) out of it. She finally argues that this "language of departure" helps the traumatized person move away from the death drive's numbing repetition by searching for and recognizing the innovation at play [Spiel] in the textual acts of repetition-compulsion within literary works instead.

Caruth concludes by claiming "the persistence of a language, or a writing, that emerges precisely as the archival resources of meaning and tradition slip away", and that this interminable language is precisely the "language of the life drive" that enables one to trace the textual circuits of persistently recurring words or figures in

\footnotetext{
${ }^{3}$ In a fascinating footnote that affixed this observation, Freud alludes to a "further observation that subsequently confirmed [this fort-da] interpretation fully". He describes Ernst, in the absence of his mother, "making himself disappear". Discovering a full-length mirror that did not completely reach to the ground, Freud noted the baby crouching down to make his mirror-image "gone”.
} 
traumatized textualities (Caruth, 2013: p. 82). For Caruth, the site of literature is thus that of the archive ${ }^{4}$ (Caruth, 2013: p. 82), and in excavating these traces of the past from texts (death drive), one may find the traces of the future (life drive) as well. In Literature in the Ashes of History, Caruth asserts that the texts of Honoré de Balzac, Wilheim Jensen and Sigmund Freud, among others, demonstrate this "persistence of language" by bearing witness to both known and unknown past traumas, therefore repeatedly returning to a future that remains beyond imagination (Caruth, 2013: p. 92). She analyses Balzac and Dorfman’s literary characters who reemerge from their individual historical "disappearances", and posits that the theoretical thinkers Arendt and Freud struggle-like the fictional characters in Balzac and Dorfman - to "claim a new mode of conceptual and historical survival in the face of a history that seems constantly about to disappear" (Caruth, 2013: p. xi). She ultimately advances that bearing witness toward the past and turning to the future brings the individual forward toward the life drive by enabling "a mode of speaking and of writing" by which one can depart toward survival from.

\subsection{The Languages of the Life and Death Drives}

To me, Caruth's contribution in Literature in the Ashes of History to trauma studies is her attempt to identify the site where the "language of departure" can begin to occur by examining the processes the traumatized engage in when crafting their interior lives in relation to the texts they write. However, I argue that recognizing these "modes of speaking and writing" first requires us to distinguish the "language(s) of the death drive" and "language(s) of the life drive" in order to achieve a better understanding of what underlying principles inaugurate the semantics exhibited in life, as well as within the repetitions of the death drive. Examining the way literary figures attempt to excavate the language they possess to bear witness or make sense of an unspeakable loss may thus inch us closer toward understanding and identifying where the "languages" the traumatized employ lie within the spectrum of the life and death drive.

I am aware that my usage of a "spectrum" of the life and death drive necessarily employs the drives as directly opposing forces. In Territories of Evil, Billias (2008) observes how this dualistic model "collapses time and again" throughout Freud's oeuvre because "strictly speaking no such separation [between the life and death drive] exists". She suggests instead "a metaphysical view of life and death as interlinked, rather than as discrete and contrasting forces” (Billias, 2008: p. 237). I am also cognizant that different ways of bearing witness and testifying to the tremendous suffering, unresolved mental anguish and existential crises of trauma should and cannot be compared. While wholeheartedly accepting the validity of these assertions, this paper maintains the capacity of the life/death drive binary to offer useful insights on how the anti-life tendency of the death drive can be externalized, sublimated or transformed into that of a positive, creative act able to trace the signs of an unimaginable past, as well as an unimaginable future.

\subsection{Juxtaposing the Languages of Trauma in Bachmann and Sebald's Fictions}

This paper posits that the literary characters in the fictions of Ingeborg Bachmann and W. G. Sebald occupy opposing ends of this ambit of the life and death drives, and consequently avers that the contrasting ways they enact the repetitiveness of personal and/or national trauma come close to performing, respectively, the languages of the "death drive" and the "life drive". I argue that Caruth's attempt to identify the site within history where trauma can be creatively animated sets a productive framework for examining how trauma can either metabolize an individual into foreclosing the world, or create a continuing dialogue with loss for the unfolding of a worldin-becoming.

Striking departures from literatures of trauma that give voice to the injuries of the traumatized, the characters in Bachmann and Sebald's fictions speak from positions of enforced complicity instead, an unwelcome implication that, I posit, has resonances with man's connivance in his own involuntary organic drive toward death. Stemming from inherited national histories of National Socialism from post-war Austria and Germany, the characters in Bachmann and Sebald's work struggle to craft their interior lives in relation to histories of oppression from such sites of incrimination. Given the constant reinstatement and blurring of the boundaries between victim and perpetrator in their prose pieces, this examination aspires to understand how specific socio-historical conditions enable textual bodies to construct "languages" of the life and death drive. Through close literary analysis, I contrast the extents to which the unnamed female protagonist in Bachmann's Malina (1971) and the

\footnotetext{
${ }^{4}$ This notion of the archive originates from Derrida's Archive Fever: A Freudian Impression.
} 
first-person narrator and fictional character Austerlitz in Sebald's (2001) Austerlitz are able to view themselves as textual beings conscious of the death drive's dominance in the aftermath of trauma, as well as how they are able to creatively pull away from it in their accounts of self toward a future hope.

While both Malina and Austerlitz explore the effects of narrativising loss, they do so in vastly different ways. The abused ways of remembrance Bachmann's unnamed female protagonist Ich enacts in Malina originates from a historical site that insists upon language's inability to figure what it cannot think. For Bachmann, postwar Austria's national forgetting of its complicity with and victimization by Nazi Germany repressed ideological connections to the country's recent past necessary to communicate personal and national memory. Bereft of the language needed to imagine a future apart from the structures that work to suppress her, the unnamed female protagonist Ich vacillates between persecution and complicity and is unable to perceive or moderate the dissimilarities between these extremes. Accordingly, the language she constructs is an inert one that only creates positions anticipating further self and historical obliteration. I demonstrate how Ich fails to reckon with the damning recursiveness of language, as well as how the language she uses makes utopia inherently traumatogenic, disallowing her traumatic history from moving forward [da] because of the immobilizing inability to articulate and subsequently gain a certain amount of mastery over the traumatic memory [fort]. Unable to reckon with her historical circumstances, she is incapable of departing from the pull of the death drive, and is inexorably destroyed. The inherited tendency of the animate to return to the inanimate in the theory of trauma not only illumines - as I will show-the desire Bachmann's female protagonists demonstrate toward fulfilling the death drive, but may also open up fragile speculations regarding the cause of Bachmann's enigmatic death.

In contrast, I advance that both Sebald's first-person narrator and the fictional character Austerlitz in Austerlitz operate from a paradoxically productive site where traumatic histories are permitted to open themselves to signification from the hermeneutic debris of loss. Because this intentional and willing mourning precedes and anticipates further loss, it comes closer to "departing toward survival" because it provides the remains of unrealized potential with expanded capacities of signification. With close reference to Eric Santner's conceptualization of "spectral materialism" in his book On Creaturely Life (2006), I show how Austerlitz's failure to trace a meaningful narrative in the unfamiliar history he inherits incongruously leads to the active construction of a "language of the life drive". I also demonstrate how he and the narrator are able to creatively trace the textual circuits of persistently recurring words or figures within his traumatized past and demonstrate how this process transforms the compulsive desire to petrify traumatic memory into a willingness to reckon with the ethical considerations of time and space involved in witnessing lost histories instead. I conclude by illustrating how this willingness to face the death drive enables both the narrator and Austerlitz to continue "departing toward survival” in their search for meaning from the site in history where meaning is precisely slipping away.

\section{Traumatized Writers Writing Trauma}

Bachmann and Sebald's biographies interminably enter the fictional narratives they produce, highlighting their personal efforts—conscious, unconscious, or both—of the Spiel intrinsic to Ernst's fort-da game, as well as their return to the traumatized fort of their own losses in order to articulate the language needed for the $d a$ of their works that could prompt their departure into survival.

\subsection{Ingeborg Bachmann}

Bachmann had been born in Klagenfurt in 1926. Profoundly impacted by the effects of Austrian remilitarization, she developed an acute awareness of the destructiveness a language of dominance could enact. She recounted that the arrival of Hitler's troops in Klagenfurt "destroyed [her] childhood", "was so horrifying that [her] memory beg[an] with th[at] day", and that "the terrible brutality" she felt from "the shouting, singing and marching" was the origin of her "first death fear" (Bachmann, 1983: p. 111) ${ }^{5}$. This, along with her turbulent relationships with men, resulted in the conviction that national and international violence arise primarily from an existing power dynamic between men and women. She explores this relationship in Todesarten (Ways of Dying), a series of interrelated stories-The Fall of Franza, Malina, and Requiem for Fanny Goldmann - that link fascism to the intimate setting of home. In the introduction to "The Book of Franza", Bachmann states that "[w]ays of dying... include crimes", that "cannot have simply disappeared from our world" just because "murder is no longer

${ }^{5}$ Ingeborg Bahmann: Wir müssen wahre Sätze finden. Gespräche und Interviews. Ed. Christine Koschel and Inge von Weidenbaum. Munich: Piper, 1983. Print (Koschel \& Weidenbaum, 1983). 
praised, desired, decorated with medals, and promoted". She asserts that because today these crimes can "hardly be perceived", though everywhere "they are committed daily", Todesarten's goal was to "produce the first evidence that still today many people do not die but are murdered", because "nothing is—if not perhaps more monstrous-than man" (Bachmann, 1999b: pp. 3-4). Suffering from addiction and alcoholism, she died in 1973 in a fire presumably started by a lit cigarette she had dropped while asleep.

\subsection{Winfried Georg Sebald}

Sebald, on the other hand, had been born in 1944. Only a year old at the end of the Second World War, he, unlike Bachmann, did not directly witness the activities of wartime Germany or the Holocaust. In 1966, he migrated to England from Wertach im Allgäu, Germany, eventually taking up a position as a professor of European Literature at the University of East Anglia. A deep sense of geographical and historical displacement from his identification as a post-war German emigrant pervades his work ${ }^{6}$, where he examines many epistemological and moral questions on how post-war, non-Jewish German writers can adequately represent the Holocaust and its aftermath. In "Air War and Literature” (Luftkrieg und Literatur), a series of lectures given in Zürich in 1997, Sebald criticizes post-war German literature for failing to authentically represent the destruction of German cities during the war because of the national repression of the history of war-time Nazism. While he correlates this guilty silence to the repression of speaking about the Holocaust in Germany, he also expresses the opinion that explicit representations of the Holocaust diminish the extent of their atrocities. Advocating instead an aesthetic of unrepresentability that can only come about by the desire to work through the epistemological problems of Holocaust representation, Sebald employs peripatetic first-person narrators with biographical correspondences in Vertigo (2001), Rings of Saturn (1999), The Emigrants (1997) and Austerlitz (2011)—usually named "Sebald"-as figures contending with personal or historical trauma, in order for him to work through such epistemological concerns within fiction. He died in 2001 of an aneurysm that resulted in a car crash, making Austerlitz his last completed work.

\subsection{Writing and Departing toward Survival}

I am cognizant that my examination necessarily involves conflating certain aspects of Bachmann and Sebald's prose with their biographies. For example, Bachmann's postulation that fascism is its most insidious in interpersonal relationships cannot be divorced from her tumultuous relationship with husband Max Frisch. Similarly, Sebald's incorporation of certain biographical coordinates into his fictional first-person narrators also highlights the correspondence between the emigrant author and his exilic characters, all of who struggle with indirect relations to past horrors through geographical and historical displacements. Nevertheless, I argue that this tenuous relationship between writing - a creative, liberating endeavor — and being read as a textual construct is precisely the site of impasse that occurs in attempting to write trauma. Accordingly, the overlap of biography and writing demonstrates how Bachmann and Sebald had attempted to creatively [Spiel] depart toward survival (life drive) by exploring the painful circumstances that shaped their personal and political consciousness (death drive). For Bachmann, this created female protagonists unable to construct history out of the repetitions of their own traumas (death drive). In Sebald's case, he made his first-person narrators exilic wanderers who creatively examine [Spiel] the line between melancholic repetition (death drive) and a kind of horrified, paradoxically productive beauty that can be found in such reiterations (life drive). Ultimately, Bachmann and Sebald's biographical overlays lend material, real-world credence to the authority imbued in Caruth's assertion of a "persistence of language" able to be traced within traumatized textualities.

However, this paper does not examine authorial intent or authors' histories, as they fall within the domain of the biographer, and not the literary critic. My expressed purpose is to investigate the sites where Bachmann's and Sebald's first-person protagonists operate from within the spectrum of the "languages" of the life and death drive via Caruth's Literature in the Ashes of History, and to show how this enables a more nuanced apprehension of the imaginative capacity needed to reckon with and articulate loss and so "depart toward survival".

\section{Ingeborg Bachmann's Ich and the Language of the Death Drive}

The second and only complete novel of Todesarten (Ways of Dying), Malina comes the closest in Bachmann's

\footnotetext{
${ }^{6}$ See Kochhar-Lindgren’s (2002) “Charcoal: The Phantom Traces of W. G. Sebald’s Novel-Memoirs” for an excellent study of how Sebald
} the author blends "Sebald" the character in the host of narrators in his oeuvre. 
oeuvre to being an autobiography. Some similarities between the unnamed female narrator Ich and Bachmann include but are not limited to being female writers who suffer at the hands of men and having the same political views on postwar Austria's petrification of history and nostalgia for its past Austro-Hungarian Empire. Unlike the other stories in Todesarten that depend on plot development and free indirect speech, Malina employs eclectic, fragmented narrative structures told in a continuous present. Through references to excerpts from the narrator's unfinished novel, stage directions, musical notations, or fragments of plays, the novel simultaneously upholds heroic and victimized versions of Austria's past through Ich's subjective suffering of this very same past, enabling the reader to trace the correspondences between her personal suffering and the collective processes of national and cultural remembrance.

Framed within the parameters of a play in what she terms the "Today" (Bachmann, 1999b: p. 1), Ich begins the novel by introducing the "cast", immediately drawing the reader's attention to her emphasis on theatricality and the narrative's position within a continuous present. Ich's Hungarian lover Ivan is introduced as a father of two who works at an "Institute for Extremely Urgent Affairs". Also defined by his job, Malina is described as one who names and categorizes historical artifacts in a military museum. In contrast, Ich's profession and addresses are "crossed out and written over" (p. 1), exposing the absent presence female employment has in the narrative because of the patriarchal structures that repress the generative forces of women. Instead, Ich introduces herself by outward appearance, "blonde hair, brown eyes, born in Klagenfurt, living presently in Vienna, District III in the Ungargasse, number 6", indicating not just her inability to construct a sense of self apart from the standards expected by the monumentalized patriarchal and national narratives she is mired within, but also why she titles her memoir someone else's name, and never reveals her own.

Living near Ivan in Vienna, Ich revolves her life around his, believing that their relationship transforms an unnamed horror she perpetually suffers from into beauty and salvation. Knowing Malina by virtue of several chance encounters, she cohabits with him symbiotically, even though the nature of their relationship is never defined to the reader. Seeming counterparts, Malina has "impeccable self-control" and is always "unamazed" by what she has to say (Bachmann, 1999a: p. 53) while she, in contrast, "reacts at once in every situation", submits "to every emotional appeal", and "suffers the losses which he notices in his detachment" (p. 164). Despite being a well-known writer, Ich never seems able to articulate this unknown terror from her past and obsessively desires to do so. It is suggested that this unnamed catastrophe does not just refer to the oppression of men against women, but also the terror faced while traversing the unknown temporal and spatial terrains of traumatic pasts. The novel is saturated with such journeys made between spaces_rooms, real and invented geographical areas, the Austrian landscape - that enact the compulsive movements of the present over the various imagined, fragmented, and insistent topographies of memory involved in remembering trauma. Because Malina is told in a continuous present, these traversals occur despite the lack of exterior plot development and narrative stasis (death drive). For example, Ich's past is represented through dream-like or nightmarish flashbacks produced from her interior psyche in the present. The numerous erratic crisscrossing navigations in her narrative suggest the difficulty of determining past, present and future from each other, and illumine how conventional conceptions of linear time are denied to traumatized subjectivities. For Ich, the word "today" is thus an "impossible" word, and "anything written about Today should be destroyed immediately" like "all real letters are crumpled or torn up, unfinished and unmailed, all because they were written, but cannot arrive, Today". The destruction of communication because of its redundancy suggests a suspension in time logic at both the singular and relational level. Ultimately, it implies not just Ich's inability of accessing meaning in the socio-symbolic order of the present, but also her awareness and acceptance of such incapacity.

Ich thus attempts to construct her personal history by fixatedly premising it upon her relationship with Ivan. The difficulty of depicting how the past violently collides with structures of remembrance leads her to believe that Ivan will employ her with the language she needs. However, this relationship is unreciprocated and oppressive; Ivan "covers [her] mouth with his hand whenever [she's] on the verge of saying something rash". In addition, as soon as Ich says she has to tell him something, he interrupts her and states that she has "absolutely nothing" to explain to him and that she owes no one "an explanation" because what she has to say is "nobody's business" (p. 16). Furthermore, Ich's wish to document the undisclosed horror of her past conflicts directly with her desire to write a "happy novel” for Ivan (p. 49). Coming across works she's written, titled "Death Styles" and "Darkness in Egypt"-a patent correlation between author Bachmann and her first person narrator-he denigrates her "obsession" with "gloom" and "sadness" and instructs her to instead write books with cheerful titles such as "Exsultate Jubilate", which makes her "mad with joy" since she’s "always mad with joy" anyway. 
Because she believes that they are working things out "effortlessly" (16), Ich "ha[s] to laugh" and "allow affliction to occur elsewhere, since there [wasn't] any [t]here” (pp. 30-31). Because her perpetrator is an unknown one structurally embedded within the systems of symbolic law she is mired within, Ich is incapable of identifying and articulating the violence enacted upon her and therefore unable to mourn the loss of her subjectivity.

\subsection{The Language of Trauma and Utopia}

Accordingly, utopia for Ich is one that yearns for a hegemonic succession of sovereign power structures in order imbue meaning to the excess demand her symbolic world exerts. Elevating Ivan to a messiah-like figure capable of giving her the words required for deliverance, she declares that he "has come to make consonants constant once again and comprehensible, to unlock vowels to their full sounding, to let words come over [her] lips once more, to solve problems and recreate connections long since disrupted". She craves that their "identical" first initials-Ich and $I$-van - "unite" for the sake of the "resurrection" of the world and asserts that, like the Christian reconciliation narrative, the wedded names would facilitate the beginning of the "first words, cautiously, once again paying heed to this world, compelling it to respect itself once more" (p. 15). Language is thus both giver and recipient of desire in the text, where "recreated connections" between vowels and consonants are able to propagate the "first words" in a genesis of perfect totality. However, this new linguistic genealogy originates from a cruel and indifferent source that not only repudiates the previously lost language but also denies it the capacity for representation, thus curtailing any blissful conception of a redemptive language able to speak and think outside the circumscriptions of the death drive.

In one of Ich's reveries, the Kagran tale depicts a perverse utopia premised upon such determinations. The clichéd plot sees a captured princess saved by a mysterious male stranger, who-for unknown reasons-has to leave her, leaving her distraught by his departure. Becoming a visionary, she foresees a reunion with him two thousand years later, in a city before a windowsill full of flowers. It is in front of such a window of flowers that Ich meets Ivan for the first time and is convinced that he is indeed the savior she had been awaiting (pp. 36-41). This suggests femaleness as a normatively traumatogenic institution where their desires are restricted and repressed by the primordial socio-symbolic order structured upon the desires of men. Unable to conceive past, present or future apart from monumentalized narratives, the Kagran tale suggests that Ich's inability to depart toward survival is not just the result of historically specific and endurable social forces suppressing advancement toward the life drive, but also the truth of the historical experience itself where women are everyday "murdered". Consequently, Ich cannot depart toward survival by establishing a resolute discourse with loss and its vestiges, since the language she needs to understand history is founded upon a retro determined suppression of subjective female structures of remembrance.

\subsection{Female Remembrance and Narration}

Eventually, Ivan abandons her, leaving her bereft of the object she had projected her linguistic salvation upon. At Malina's urging, Ich confronts the pain, incest, violence and torture of her childhood in an attempt to solidify her identity. Silenced, raped, and murdered by her father in an extended series of hallucinations and fragmented dream narratives, her memories represent traumatic images from her past as well as those of collective chronicles of suffering such as the deportment of Jews in Europe in the 1930s and 1940s. Peculiarly, Ich's father, who is the primary perpetrator of these atrocities, is described as having her mother's face (pp. 152-153), suggesting again a genealogy of terror originating from predetermined historical traumas. Ich believes that this transhistorical perpetrator/victim constellation will eventually culminate in a "cemetery of murdered daughters" where she will be buried alongside all other women (p. 130). Rather than simply being the product of socio-historical events, the obscured atrocity of fascism can be traced back to identification with the victorious hegemonies inherent and at play in the interactions between people. Ich concludes that history is thus "always war", "always violence", "always struggle" and does not end with peace but continues in spite of it (p. 155). To this, Malina advices her to "stop struggling" and "learn a new style of struggle" (p. 207) instead, suggesting that since femaleness is perpetually given over to the permanence of history's victorious hegemonies, the only form of resistance women can undertake is to adapt to the inevitable subsequent successions of sovereign power structures.

Malina increasingly takes on the role of therapist or analyst in listening to, interrogating, and affirming Ich's account of self. It becomes clear that he and Ich are two sides of the same character, and that a new male narrator is insidiously appropriating the voice of the first-person female one. Instead of the first-person female narra- 
tor confirming his subjectivity as a character in her memoir, Malina alienates Ich from her role, resulting in her needing him to explain her own words to her (p. 123). He slowly morphs into the perfect narrator by appearing to know everything she does; "ha[ving] nothing to hide"; and being "distance personified". Because he does not suffer the emotional pain she feels upon reckoning with her past, he is capable of objective narration since nothing is too painful to be repressed (p. 198). Stating her envy, Ich attempts to imitate him but "can't pull it off" (pp. 198-199). While still the speaking agent providing the linguistic signs constituting the text, she gradually becomes the object of utterance instead. When Malina tells her to "stop falling down all the time. Get up. Go out, have fun, neglect [him], do something, anything!”, she declares that she "get[s] up for [his] sake, [she'll] eat one more time, but only to please [him]" (p. 202), indicating her incapacity to develop a creative, future-oriented agency apart from the authority and legitimacy of Malina’s new narrative.

\subsection{The Language of the Death Drive}

Nevertheless, there is a moment where Ich attempts to reassert control. In a charged scene, she asks Malina to explain why "an old piece of paper has again surfaced" which describes him on a trip he had taken in Lower Austria. She does not let him read it, only the title: "Death Styles", as well as another note titled "Death Stales". Though professing her incomprehension as well, she challenges him to explain this incongruous choice of diction, and defiantly proclaims his inability to guess what she wrote in her story of his trip (p. 190). Reminded of his identity as a fictional construct and his incapability of interfering with either her past or his, in the only show of violence between the two, the calm, rational Malina hits her (p. 192). This defiant scene illustrates Ich exercising authorial agency by reasserting her role as creator, but also indicates her inability to access or trace any signification within the archive of her own writing as she only has the titles of her work to brandish, and not their contents. While recognizing the unarticulated-unarticulation she struggles with, she however possesses no tools or resources to express this knowledge of hurt and loss. The rebelliousness demonstrated thus bears little creativity and eventually negates the very possibility of agency, as the site she operates from is one that knows that language will turn back on her. Cognizant that the act of writing she flourishes in front of him has approached its expressive limit-the perilous threshold between representation and silence-there is nothing she can say but the "nothing" of saying, and a helpless, dull enactment of the disappearing act of her speaking. After this charged scene, she goes out for a normal dinner with Malina, displaying a lack of energetic determination in maintaining her subjective stance, suggesting that unlike the child who cries fort and then $d a$, her desire to reclaim the meaning of her loss [da] is negated by her inability to first give it up [fort], resulting in a patient metabolism into the in animation of a world foreclosed. Not simply one of dehumanization or lack of excited energy, Ich's contented passiveness operates from a site where the spatial architecture of memory has broken down, and where self-acceptance as a determined, traumatized by-product of overriding social structures is thus mandatory, it being the only option open to her.

When Malina asks Ich if she still wants to claim subjectivity, a "Me", she replies that she is only now beginning to "love it", and that she "shall love it as [her] neighbor, as [him]!" (p. 208). This indicates her growing blissful acquiescence of having Malina annex her role as first-person narrator and demonstrates the dangers of monolithic thinking in its ideological, intellectual and linguistic circumscription of a world-in-becoming. After a prolonged struggle, Ich declares, "I have not grown any closer to myself. I have only watched one unknown woman slide further and further into another" (p. 194), and concludes that she "live[s] in Ivan and die[s] in Malina” (p. 223). Finally destroyed, she disappears through a crack in the wall while the male narrator Malina lives on, throwing her things out and disavowing Ich's existence entirely. Narrated all the while in a continuous present tense, the novel ends with the only line in the past: "[i]t was murder", suggesting the completed cycle of the perennial recursiveness that Ich's language had been trapped in, and how her desire to reclaim the meaning of her loss [fort-da] had been annulled from the very beginning of the novel, the fulfillment of the death drive being an already foregone conclusion.

\section{Sebald's Austerlitz and the Language of Departure}

Unlike Bachmann's Malina, Sebald's Austerlitz is his least biographical work, and is thus perhaps why it comes the closest in his oeuvre to being a novel. In contrast to his earlier fictional works, Austerlitz exhibits more plot structure, a clearer distinction between memoir and fiction, the omission of the name "Sebald", and also-for the first time - the introduction of a fictional protagonist apart from the first-person author-narrator. 
Jacques Austerlitz, an architectural historian, befriends and narrates his story to the first-person narrator. He arrived in Britain in 1939 as an infant refugee from Czechoslovakia, and had been adopted by a preacher who named him Dafydd Elias. Eventually, he discovers his real name and mysterious origins, which haunt him over the years, leading him to "accumulate[e] knowledge" to serve as "a substitute or compensatory memory" able to deliberately suppress his painful history (Sebald, 2011: p. 140). This "self-censorship of [the] mind" later led to a "total paralysis of linguistic faculties" and multiple nervous breakdowns. In his attempts to "assemble and recast" the fragmentary shards of his past, Austerlitz perceives language as a self-consuming structural paradox that makes it impossible to read or write. He describes this linguistic and existential paralysis as a "latent illness" threatening to "erupt", insinuating that the debris of language is a primordial state one inhabits in the wake of the trauma of living. The use of an underlying illness as metaphor for a transhistorical traumatic linguistic paralysis also accentuates Freud's assertion that the life drive is subordinate to the death drive, and highlights language's imperative life-giving character for proper psychical and physiological functioning. "Turning away from [himself] and the world” (Sebald, 2011: p. 121), Austerlitz's personality "disintegrates” and his unbalanced life becomes the vehicle by which the morphological struggle to tell is enacted. He declares that out of all the incomprehensible signs of language, he least understood what he himself had written. This suggests that, like Bachmann's Ich, the inability to view oneself as a textual construct incapacitates the possibility of articulating the construction of self-identity as it continues developing after the event of trauma. In relation to "the persistence of a language, or a writing” Caruth claims is inherent to every traumatized individual, Austerlitz's linguistic paralysis and incomprehension suggests that the failure to trace this interminable language within its primitive state of fracture would inevitably, tend toward the death drive.

Nevertheless, Austerlitz does begin to actively attempt to construct a "language of the life drive" by grappling with the "language of the death drive" that had characterized his aforementioned linguistic struggle. Unable to locate a site within his lost personal history by which to operate from, Austerlitz makes the decisive move to go to Prague and search for his origins. There, he meets Vera, a close friend of his lost parents whose stories prompt the return of many of his inhibited memories, and who tells him his mother had been deported to the Theresienstadt concentration camp during the war. Reckoning with his trauma and how to articulate it offered the potential of a future more hopeful than that of the linguistically anaesthetizing reiteration of the death drive. While the temporal and spatial wanderings that Austerlitz henceforth undertakes ubiquitously lead back to the same intertextual or geographical returns, however, unlike Ich's patient metabolism into the in animation of such damning reiterations, for Austerlitz these returns incite the anticipation of being able to uncannily discover the full measure of horror in any beatific moment.

\subsection{Representing the Surplus Animation of Loss}

As memories surface, Austerlitz feels "as if time did not exist at all”, only "various spaces interlocking" according to "the rules of a higher form of stereometry", between which "the living and the dead can move back and forth as they like". To Austerlitz, the living are "unreal in the eyes of the dead" and only "appear in their field of vision" in "certain lights and atmospheric conditions" (p. 185). This hypertrophied depiction of time and history suggests the present is not simply a bridge between past and future, or a "now" in a linear conception of temporality, but that which consists of irruptions of "interlocking spaces" between past and future that the living can access only belatedly. For example, it is described that the "trails of light" left behind by moths did not really exist, but were "phantom traces" created by the "sluggish reaction of the human eye, appearing to see a certain afterglow in the place from which the insect itself, shining for only the fraction of a second in the lamplight, had already gone” (pp. 92-93). This human shortsightedness insinuates the past as a series of missed consciousness and possibilities that speak out of time from a site where the future dwells within moments already beyond remembrance. Any attempt to represent the tedious, compulsive repetitions of history can thus only bear witness to the difficulty characterizing the process of accessing that which has already been lost, since the past is always beyond the reach of the present, where one is only able to perceive "everything fading before [one's] eyes" (p. 88).

Austerlitz depicts the terror that accompanies this desire to petrify that that is vanishing through recurring motifs of wide-open, terrified eyes in the glare of synthetic light. There are many instances of characters looking at slivers of light and what they illuminate, for instance, "[w]here there had been nothing a moment ago but fathomless gloom, there now shone a little village... everything grew lighter and lighter...” (p. 49). However, the novel's opening image of synthetic lights in a Nocturama haunts the remainder of the text, rendering suspect any 
subsequent descriptions of natural light and what they reveal. The narrator ponders the "topsy-turvy miniature universe" of the animals in the Nocturama, where the electric light was turned off "when real night fell", so that as day dawned they could "fall asleep with some degree of reassurance" (p. 5). This repeated motif of terror-struck, wide-open eyes suggest that capturing a vanished past or gaining mastery over one's trauma is only attempted while striving toward a "light", or convinced that understanding unimaginable pasts or futures is an act that is redemptive. Believing that these constructed beliefs or philosophies can "penetrate the darkness" (p. 5) of the unknown, those in the present-like the deceived nocturnal animals-can "fall asleep reassured" in the false comfort provided in the imposed darkness of day. As a result, "[t]he darkness does not lift but becomes yet heavier" because of "how little [the living] can hold in mind" and how much wide-open eyes are able to comprehend and preserve the continuity of life from a world that is continually "draining itself" (p. 24).

\section{2. "Spectral Materialism" and Narrating Trauma}

Nevertheless, the image of perpetually wide-open, terrified eyes also suggests the willing undertaking to tarry with the unknowable space beyond existence instead of repetitively and compulsively defending against it. This predisposition to contend with such insistent and painful impenetrability is precisely the substructure of the distance and language required from the site within history Caruth asserts one can depart toward survival from. Since the death drive that tends toward a stage of inanimate matter is in direct opposition to life in its complete biological sense, a traumatized person readily reckoning with his psychic wounds can be seen as a biologically anti-survival undertaking, as this drive risks the possibility of a final, irreversible outcome of death. Driven by the desire to resuscitate an interminable truth lying beneath the accretions of time, Austerlitz is able to approach his traumatic repetition-compulsion as separate from classical temporal orders and narrative concordances by narrating his story to the narrator. Able to operate from a site both attached to and detached from his trauma, his "language of the death drive" is able to begin to prompt the "language of the life drive" by resurrecting the uncanny surplus animation of his mislaid and painful losses. In On Creaturely Life, Eric Santner builds upon the principles of historic materialism in explaining this revived "undeadness" of the past, positing "[t]he opacity and recalcitrance" of nature's materiality is, paradoxically, most palpable when encountered as "a piece of human history that has become an enigmatic ruin" beyond "the capacity of the living" to "endow it with meaning" or integrate it into the symbolic universe (Santner, 2006: p. xv). He posits a "spectral materialism” (p. 159) at work in Sebald's oeuvre, defining it as that which includes "a capacity to register the persistence of past suffering" that has been "absorbed into the substance of lived space, into the "setting" of human history" (p. 57). In the fortress of Breendonk in Austerlitz, the narrator contemplates the spectral materialism of the straw-mattresses that lay "shadow-like... which had become thinner and shorter because the chaff in them disintegrated over the years, shrunken", as if they were "the mortal frames of those who lay there in that darkness" (Sebald, 2011: p. 24). Santner advances that this approach towards history is a deferential dependence upon "performative acts of witnessing" that transform "creaturely deposits into a form of deposition" (p. 75, italics in original). This imaginative endeavor is one that the narrator in Austerlitz performs by imbuing traumatic histories with the embodied presence of things that had once been there, an approach that also understands distinctive historical materials and events as inextricably embedded within the larger course of natural history. Santner asserts that in Sebald's work, "materiality [thus] does not merely signify the 'natural' corruptibility of all things earthly", but "an index of their participation in the violent rhythms of human history" instead (p. 75). Able to inventively trace the participation of material objects from their positions within natural history, Austerlitz is able to similarly grasp himself as a traumatized textuality where the excesses within the textual circuits of his indefatigable past can be pursued - if not by him, then by the narrator. Both their acts of narrating Austerlitz's story enact the disappearance of the monumental narratives that had prescribed understanding his past [fort], therefore opening up possibilities of moving his seemingly gridlocked history forward [da].

Santner critically stresses that this manner of witnessing history is "not as a resurrection" or an "animation of the dead" but "a de-animation of the undead" instead (p. 129, italics mine). While the prefix re in the term "reanimation" signifies a reversal of events, de connotes a removal as well as intensification. In viewing singular events as de animated, sedimented residue dregs of history, it is not empathy that one is attempting to achieve, or, phrased prosaically, "trying to see the world from someone else's point of view". Instead it is the effort of registering the "blind spots" in efforts to apprehend the totality of such unknowable histories, and "unpack[ing] the stresses [that are] condensed [within] this blindness" (p. 58). This endeavor necessarily involves constructing history from a position where the unnerving and chastening indifference of a world toward its material and liv- 
ing entities is accepted, in order to move away from the death drive's numbing and empty repetition and toward the option of recognizing the innovation at play [Spiel] in the textual acts of personal or historical witnessing instead. Approaching traumatic memories in this way thus has an ethical animation devoid of any temporal or hermeneutical totalization, impelling the person in the present-be it the traumatized person or his listener-to the responsibility he owes it, accept his relationship with it, and be called out of himself as the object of address. This call from the past can be seen when Austerlitz sees a photograph of himself as a boy and recounts feeling "the piercing inquiring gaze of the page boy" who "had come to demand his dues" and was waiting for him "to accept the challenge and avert the misfortune lying ahead of him" (Sebald, 2011: p. 184). While the image of the past demanding its dues is indisputably one of reproach, the image is also one of future hope, as Austerlitz's cognizance of his past as an archive calling out to him suggests that the uncanny surfeit animation of absent and painful losses can be traced (death drive), and fragments of the future found in the process (life drive).

An individual's lucid and tenacious awareness of his movements toward the pull of the death drive may-like Ich in Bachmann's Malina-intimate an impasse in attempting to represent a history of suffering. However, understanding this impossible position as the result of a moment of choice may enable the gaze toward the past to be utilized creatively towards a future redemptive hope, and provide a way of intervening into dimensions ostensibly barred from new opportunities for collective life. This ineludibly implies a gaze both immobilized and emancipating; a position encapsulated in a porcelain group Austerlitz sees of "a hero on horseback turning to look back, as his steed rears up on its hindquarters, in order to raise up with his outstretched left arm an innocent girl already bereft of her last hope... to save her from a cruel fate not revealed to the observer". In this image that is "[t]imeless as that moment of rescue, perpetuated but forever just occurring" (p. 196), it is significant that what is paralyzed isn't an unproductive witnessing of an irreversibly moribund world, but the demand for rescue and potential for hope instead. Ultimately, this image of the past waiting for the present to respond to its summons intimates from the addressee a certain kind of receptivity, a special attunement, and a willingness and ability to engage with history's opacity and recalcitrance as it simultaneously rests and imposes itself upon the present, a capacity Bachmann's Ich could not access.

\subsection{The Language of the Life Drive}

While providing hope for departing from the pull of the death drive, Caruth and Sebald emphasize that these movements of return never come full circle or provide any comprehensive curative formula for cure. Nevertheless, Austerlitz demonstrates that turning back to reckon with the blind spots within the monolithic narratives of history can lay one open to the coming of another and thus, facilitate the potential of advancing toward the drive for life, an impulse that lies at the heart of the practice of psychoanalysis. Speaking of his theory of trauma in Beyond the Pleasure Principle, Freud states, "[w]hat follows is speculation, often far-fetched speculation, which the reader will consider or dismiss according to his individual predilection. [His own essay] is... an attempt to follow out an idea consistently, out of the curiosity to see where it will lead” (Freud, 1999: p. 606). In the same way, the network of repeated images that structure the formal analogue of Austerlitz's meandering stories-wide-open eyes, monstrous buildings, star-shaped architectures, cemeteries, transparent women, among others - challenges the reader to respond to and persevere with its hypertrophied representation of history; to "accept the challenge and avert the misfortune lying ahead" by pursuing and constructing something out of the excess animation that characterize these ceaseless intertextual returns, thereby coming closer to excavating the interminable truths enshrouded beneath the accumulations of history.

Even though he doesn't find his parents, Austerlitz's continuing journey at the close of the novel suggests the future prospect that he one day will, insofar as he continues to reckon with the unactualized possibilities of his past calling out to him. The ending of Austerlitz withholds from the reader the anticipated moment of rescue, keeping him-like the above-mentioned porcelain figure-frozen in abeyance. This fissure in meaning opens up future spaces for change as, like Santner posits, the "dimension of human existence called into being" at this site is where the "will to power... is at its most intense" (Santner, 2006: p. xv). This will to power is Nietzsche's life-affirming reality, that of the "language of the life drive"- the underlying life principle inaugurating life and behavior - extending its force from the "language of the death drive” Austerlitz had been struggling against. His choice to continue with his wanderings is therefore-unquestionably-a creative endeavor to consolidate power or meaning over his enigmatic past, having reached the site within history where trauma can be worked through or narrated. Here, it is generative to recall that Austerlitz's decision to tell the narrator his story was prompted by 
an image of the biblical ark beneath a rainbow, where a dove is returning carrying an olive branch. This image of redemption and mercy is followed by Austerlitz telling himself he "must find someone to whom he could relate his own story, a story which he had learned only in the last few years and for which he needed the kind of listener [the narrator] had once been". In the narrator's subsequent creative fashioning of his story, Austerlitz was thus able to exceed "the history of countless places and objects which themselves have no power of memory" and which thus are "never heard, never described or passed on" (Sebald, 2006: p. 24). While distinctly unable to find the means to synthesize the discordances of Austerlitz's story, the narrator's willingness to attend to his traumatized past is the immobilized moment of rescue where liberation never arrives, and which is yet also forever on the way. The language employed by the narrator is thus that which is aware of the "astonishing, positively imperative internal logic" a "language of departure" advancing toward survival requires.

This almost absurd fissure in temporality and understanding outside comprehensible narrative frameworks never veers into anarchy, but understands its inability to create any kind of easy concordance in meaning. The site where the uncanny surplus animation of the "language of the life drive" within repetition-compulsion can be found is therefore that where the future is continually being belatedly informed by the past that shapes it; the place where both narrator and Austerlitz can begin to trace the textual circuits of his fragmented, traumatized history and unfold a world-in-becoming based upon the remains of the unrealized potentials of the past, as well as the unimaginable possibilities of the future.

\section{Conclusion}

Establishing a continuing dialogue with loss and its remains through the process of de-animation necessitates the spectrum of the life/death drive in order to locate oneself in relation to the significances being traced from the hermeneutic wreckage of loss. While Bachmann's unnamed female protagonist Ich is passively assimilated into the monolithic, recurring narratives of the death drive, Sebald's first-person narrator and character Austerlitz are - in their seemingly helpless repetitions and uncanny intertextual returns-able to maneuver their positions [Spiel] in relation to the ever-shifting points of convergences, ontologies and localities of trauma in order to excavate past and future from the archives of natural history.

Finally, the willingness of readers to contend with and navigate the ever-vacillating emplacements of the language of trauma along the spectrum of the "language of the life drive" and "language of the death drive" enacts the process of constructing and recovering accounts of self from an interminable "language of the life drive". By reading representations of trauma along the ambit of the languages of the "life drive" and "death drive", readers exercise the "astonishing, positively imperative internal logic" needed to contend with and articulate personal and national loss in relation to themselves that ultimately enables them to construct their own "language of departure" from a site that, as Caruth declares, "does not repeat the unconscious origin of life as death, but creates a history precisely departing toward survival” (Caruth, 2013: p. 9).

\section{References}

Bachmann, I. (1999a). Malina (P. Boehm, Trans.). Teaneck: Homes \& Meier Publishers. (Original Work Published 1971)

Bachmann, I. (1999b). The Book of Franza \& Requiem for Fanny Goldmann (P. Filkins Trans.). Evanston, IL: Northwestern University Press. (Original Work Published 1995)

Billias, N., Ed. (2008). Territories of Evil. Amsterdam: Rodopi.

Caruth, C. (1996). Unclaimed Experience: Trauma, Narrative, and History. Baltimore: Johns Hopkins University Press.

Caruth, C. (2013). Literature in the Ashes of History. Johns Hopkins University Press.

Freud, S. (1999). “Beyond the Pleasure Principle”. The Freud Reader. New York: W.W. Norton \& Company. (Original work Published 1920)

Göttsche, D. (2011). Research on Ingeborg Bachmann: Quo Vadis? The Modern Language Review, 106, 495-501.

Kochhar-Lindgren, G. (2002). Charcoal: The Phantom Traces of W. G. Sebald's Novel-Memoirs. Monatshefte, 94, 368-380.

Koschel, C., \& Weidenbaum, I., Eds. (1983). Ingeborg Bahmann: Wir müssen wahre Sätze finden. Gespräche und Interviews. Munich: Piper.

Santner, E. (2006). On Creaturely Life: Rilke, Benjamin, Sebald. Chicago: University of Chicago Press.

Sebald, W. G. (2011). Austerlitz (A. Bell Trans.). New York: Modern Library.

Whitehead, A. (2004). Trauma Fictions. Edinburgh: Edinburgh University Press. 
Scientific Research Publishing (SCIRP) is one of the largest Open Access journal publishers. It is currently publishing more than 200 open access, online, peer-reviewed journals covering a wide range of academic disciplines. SCIRP serves the worldwide academic communities and contributes to the progress and application of science with its publication.

Other selected journals from SCIRP are listed as below. Submit your manuscript to us via either submit@scirp.org or Online Submission Portal.
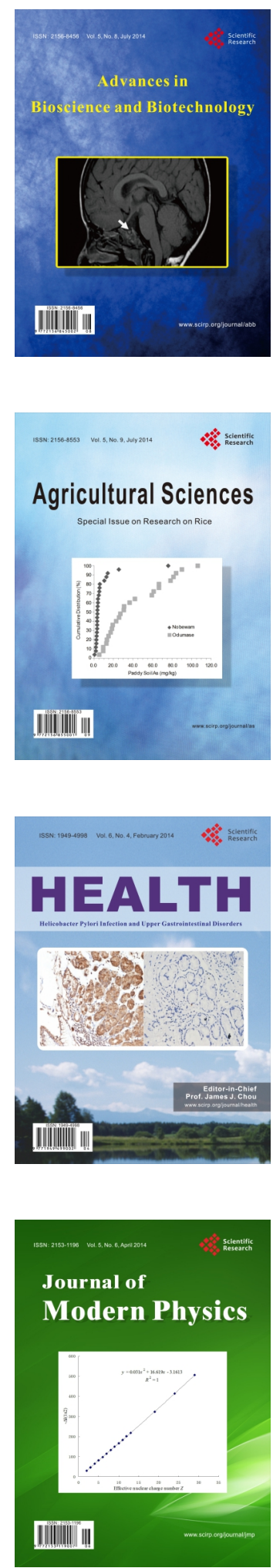
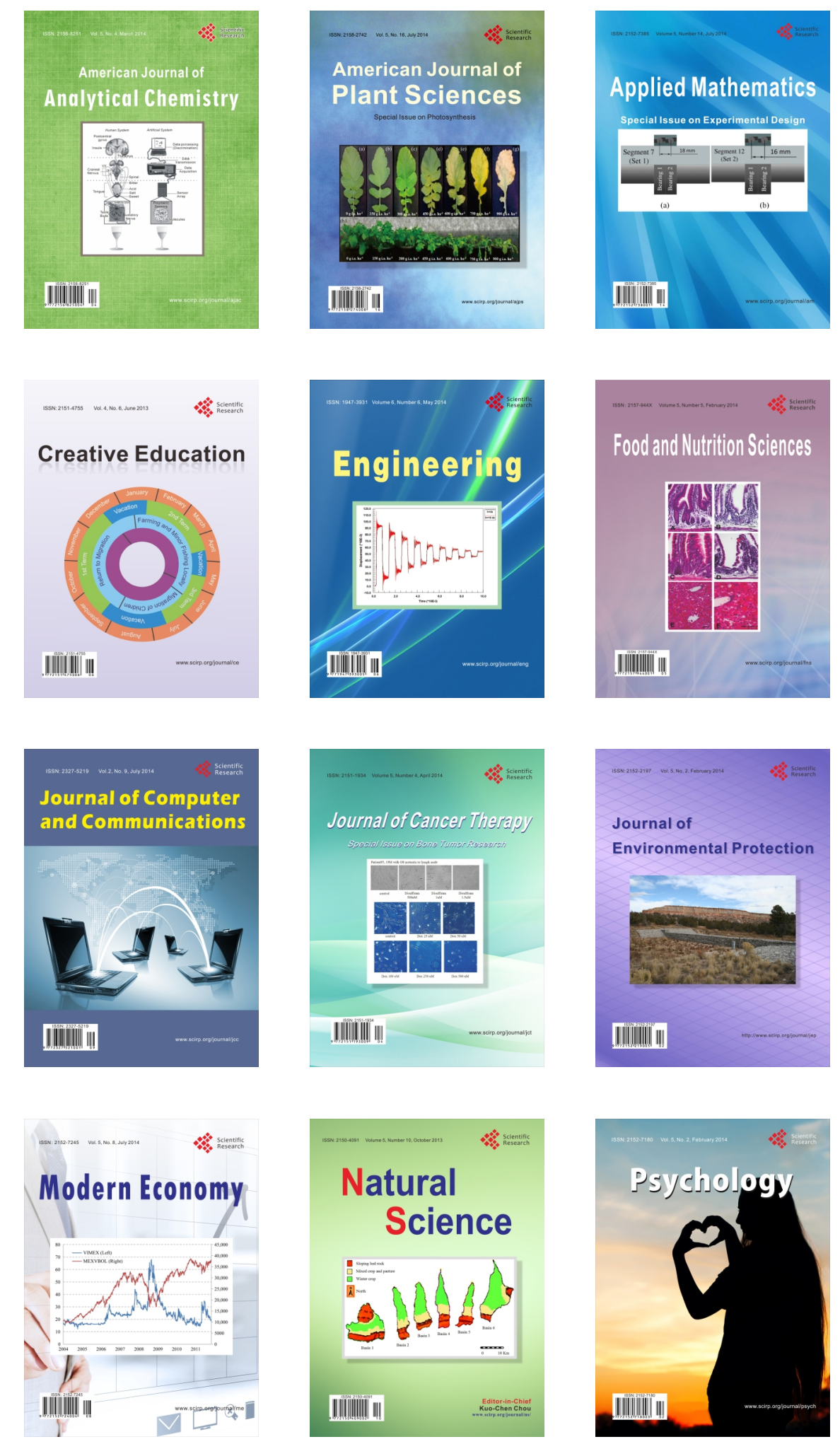